\title{
OPEN Chemical and spectroscopic signatures of resins from Sumatra (Sarolangun mine, Jambi Province) and Germany (Bitterfeld, Saxony-Anhalt)
}

Przemysław Drzewicz ${ }^{1 凶}$, Beata Naglik², Lucyna Natkaniec-Nowak ${ }^{3}$, Magdalena Dumańska-Słowik ${ }^{3}$, Paweł Stach ${ }^{3}$, Mirosław Kwaśny ${ }^{4}$, Jakub Matusik ${ }^{3}$, Rastislav Milovský ${ }^{5}$, Janusz Skonieczny ${ }^{6}$ \& Dorota Kubica-Bąk ${ }^{3}$

Fossil resins from Miocene coal deposit (Sarolangun mine, Jambi Province, Sumatra, Indonesia) have been analysed using spectroscopic methods: Raman Spectroscopy (RS), Fourier Transform-Infrared Spectroscopy (FT-IR), ${ }^{13} \mathrm{C}$ Nuclear Magnetic Resonance $\left({ }^{13} \mathrm{C}\right.$ NMR), Fluorescence Spectroscopy (FS), and Gas Chromatography-Mass Spectrometry (GC-MS) in order to describe their diagnostic features. Simultaneously, glessite, a fossil resin from Upper Oligocene Bitterfeld deposit (Saxony-Anhalt, Germany), originating from similar botanical sources (i.e. angiosperms) was tested with the same analytical methods in order to find similarities and differences between the resins. The resins differ in colour, transparency and amounts of inclusions (resins from Sumatra-yellow, and transparent with few inclusions; glessite-brown-red, translucent with wealth of inclusions). In general, the IR and RS spectra of these resins are very similar, probably because the glessite colour-changing additives can be very subtle and non-observable in the infrared region. The RS spectra revealed also a slight difference in intensity ratio of the $1650 / 1450 \mathrm{~cm}^{-1}$ bands $(0.56$ and 0.68 for Sumatra and Germany resins, respectively), indicating a differences in their maturation process. The resins from Sumatra seem to be more mature than glessite from Germany. The excitation-emission (EM-EX) and synchronous spectra showed unique, chemical compositions of these resins, which are different one from another. The GCMS data for Sumatran resins, dominated by sesquiterpenoids and triterpenoids (amyrin), confirmed their botanical origin (angiosperms as their biological affinities). The sesquiterpenoid biomarkers with cadine-structures suggested the glessite underwent more advanced polymerization processes, which does not correlate with its RS spectrum. The geological factors, the environmental conditions of resin deposition, and later various diagenesis processes may have influenced the maturation and crosslinking of compounds. Despite the genetic similarity of the resins from various part of the world, Sumatra and Germany, advanced techniques such as Gas Chromatography-Mass Spectrometry and Fluorescence Spectroscopy were the most useful to find the differences between them. These differences are predominantly a result of different diagenetic transformations of the resins.

The fossil resins are transformation products of exudates from coniferous and deciduous trees that existed on Earth from millions of years ago. They were preserved to present day mainly due to compound polymerization and cross-linking, taking place during their diagenetic or/and catagenetic alterations ${ }^{1}$. Fossil resins are found in

\footnotetext{
${ }^{1}$ Polish Geological Institute-National Research Institute, Rakowiecka 4, 00-975 Warszawa, Poland. 2Polish Geological Institute-National Research Institute, Upper Silesian Branch, Królowej Jadwigi 1, 41-200 Sosnowiec, Poland. ${ }^{3}$ AGH UST, University of Science and Technology, Faculty of Geology, Geophysics and Environmental Protection, Mickiewicza 30, 30-059 Kraków, Poland. ${ }^{4}$ Institute of Optoelectronics, Military University of Technology, Gen. S. Kaliskiego 2, 00-908 Warszawa, Poland. ${ }^{5}$ Earth Science Institute, Slovak Academy of Sciences, Ďumbierska 1, 97411 Banská Bystrica, Slovakia. ${ }^{6}$ tukasiewicz Research Network-Polish Center for Technology Development, Stabłowicka 147, 54-066Wrocław, Poland. ${ }^{\square}$ email: przemyslaw.drzewicz@pgi.gov.pl
} 
sediments of geological age spanning from Carboniferous to Cenozoic; however, they are mostly accumulated in layers dating from the Paleogene and Neogene periods ${ }^{2}$. In many cases, it is believed that the age of the resins is the same as the age of the resin-bearing sediments; however such assessment may be inaccurate due to the frequent redeposition of resins in younger geological environments. The complex transportation and postdepositional processes affect the chemical composition and spectroscopic properties of resins.

The age and origin as well as the diagenetic alterations of fossil resin in various geological environments worldwide are still disputable despite numerous investigations $s^{3,4}$. It is believed that many of the fossil resin features such as microhardness $s^{5-7}$, spectroscopic fingerprints ${ }^{8-10}$ and thermal properties ${ }^{11-13}$ may correlate with their age. In earlier investigations, it was found that the maturation of fossil resins has been influenced by various geological factors (e.g. volcanism, hydrothermal heating), not aging itself ${ }^{8,10,11,14-16}$.

The widely accepted classification system of fossil resins, proposed by Anderson and Winans ${ }^{17}$, Anderson et al. ${ }^{18}$ and Anderson and Botto ${ }^{19}$, is only based on chemotaxonomy. Hence, fossil resins, occurring in various parts of the world, but showing similar chemical compositions that are frequently caused by close affinity with the parent trees, are classified in the same group, e.g., Indonesian resins are found in the same group as glessite from Germany. Sumatran resins are from the trees of the Dipterocarpaceae species, belonging to the angiosperms group $^{20-24}$. Leelawatanasuk et al. ${ }^{25}$ found they could be easily distinguished from resins of other localities worldwide (Baltic areas, Dominican Republic and Myanmar) based on their distinct inclusions and characteristic IR spectrum. Recently, resins from the Sarolangun mine in Sumatra (Jambi Province) were studied by Naglik et al. ${ }^{16}$. Three varieties of Sumatran resins, that formed one large aggregate, differed in colour, transparency and amounts of impurities. The first resin type (I) had a light-yellow colour, a high transparency, and relatively small number of inclusions. The second (II) was represented by translucent resins of colour graduating from orange to brown. This variety was mainly accumulated outside the tree trunk, and hence, hosted a greater number of different natural, organic and mineral inclusions. The third variety (III) was a white-grey and opaque type of resin with a foam-like structure. It was also most likely to have been secreted outside the tree trunk, and then flowed down to the forest bedding. Contrary to the Indonesian resins, the late Oligocene glessites from Bitterfeld were extensively investigated by Krumbiegel, Kosmowska-Ceranowicz and Wolfe ${ }^{26-33}$.

Glessite is defined as being "opaque reddish brown to brown fossil resins with some angiosperms as its botanical source" ${ }^{34}$. Kosmowska-Ceranowicz and Vávra ${ }^{35}$ noted that the infra-red spectra of Sumatran resins were very similar to the shape of IR spectra of glessite found in the Bitterfeld deposit (Saxony-Anhalt, Germany). Recently, Matuszewska ${ }^{9}$ discussed the structural similarity of resins from Borneo to resins of glessite type from Bitterfeld. The similarity of the resins IR spectra was explained by similarity of chemical composition, primarily to the content of cadinene type compounds (sesquiterpene group), and triterpenoids in those resins. Matuszewska ${ }^{9}$ did not find sufficient proof to confirm that origins of both resins are trees belonging to the family of close kinship. As a result, the name glessite in relation to Malaysian resins was disputable.

The main aim of this study is to elucidate the source of the Sumatran resins and their transformation pathways through various geological processes. Hence, a comparison of fossil resins originating from similar botanical sources, but from different environments was made, in order to reveal the influence of the palaeogeographical provenience and geological processes affecting the chemical composition and spectroscopic characteristics of the analytical material. Accordingly, the study is focused on the fossil resins from Sumatra (Jambi Province, Sarolangun) and glessite from Germany (Saxony-Anhalt, Bitterfeld). Both resins are of angiosperms origin (flowering plants), and are classified into Class II based on Pyrolytic Gas Chromatography coupled with Mass Spectrometry (Py-GC-MS), and Group B based on Nuclear Magnetic Resonance Spectroscopy ${ }^{36}$. The characterization of the resins was carried out by means of optical observations, microhardness testing supported by various spectroscopic methods, such as: Fourier Transform Infra-Red Spectroscopy (FT-IR), Raman Spectroscopy (RS), Fluorescence Spectroscopy (FS), ${ }^{13} \mathrm{C}$ Nuclear Magnetic Resonance (NMR), and Gas Chromatography-Mass Spectrometry (GC-MS). The aim of the study was also to find the most selective analytical tool for tracking the difference in chemical composition of fossil resins from a similar botanical origin that formed and altered in different geological conditions. Furthermore, this contribution is a kind of resumption of our previous studies on Sumatran resins ${ }^{16}$, providing additional data on their similarities and differences to glessite, which coexist within the same classification based on GC-MS class and NMR group.

\section{Geological settings and palaeogeographic background}

Sarolangun mine, Sumatra, Jambi Province, Indonesia. The investigated specimens of Indonesian resins come from the waste dumps of Sarolangun mine in the South part of the Sumatra Island. The fossilized resins were found within coal and lignite beds dating to the early Miocene (20-23 Ma). Stratigraphically, these deposits belong to Talang Akar Formation, the part of South Sumatra Basin ${ }^{22}$. The size of the resins varied, from very small (few $\mathrm{mm}$ in a diameter) to very large specimens (weighting several hundred grams).

The Talang Akar Formation represents a sedimentary cycle extended from late Oligocene to the early Miocene epoch $^{37}$. It is the retrogressive unit with shales and sandstones, deposited in a fluvio-deltaic environment building the upper level of the formation profile ${ }^{38}$. This unit is overlain by the early and middle Miocene sediments, representing the transgressive depositional systems. All of those formations were uplifted, folded and faulted due to the Pliocene-Pleistocene orogeny ${ }^{37}$, associated with volcanic activity (Fig. 1).

During the Cenozoic era, Sumatra had a warm and humid climate. It was a part of southern Sundaland located at latitudes $\pm 10^{\circ}$ of the equator, with a palaeoclimate favorable for peat formation ${ }^{39}$.

Germany, Saxony-Anhalt district, Bitterfeld deposit. The samples of glessite originate from the Bitterfeld region (Fig. 1) which is considered to be the largest deposit of brown coal in the district of SaxonyAnhalt, Germany ${ }^{32,40-46}$. The Bitterfeld fossil resins are linked to the Bitterfelder Bernsteinschluff horizons in the 

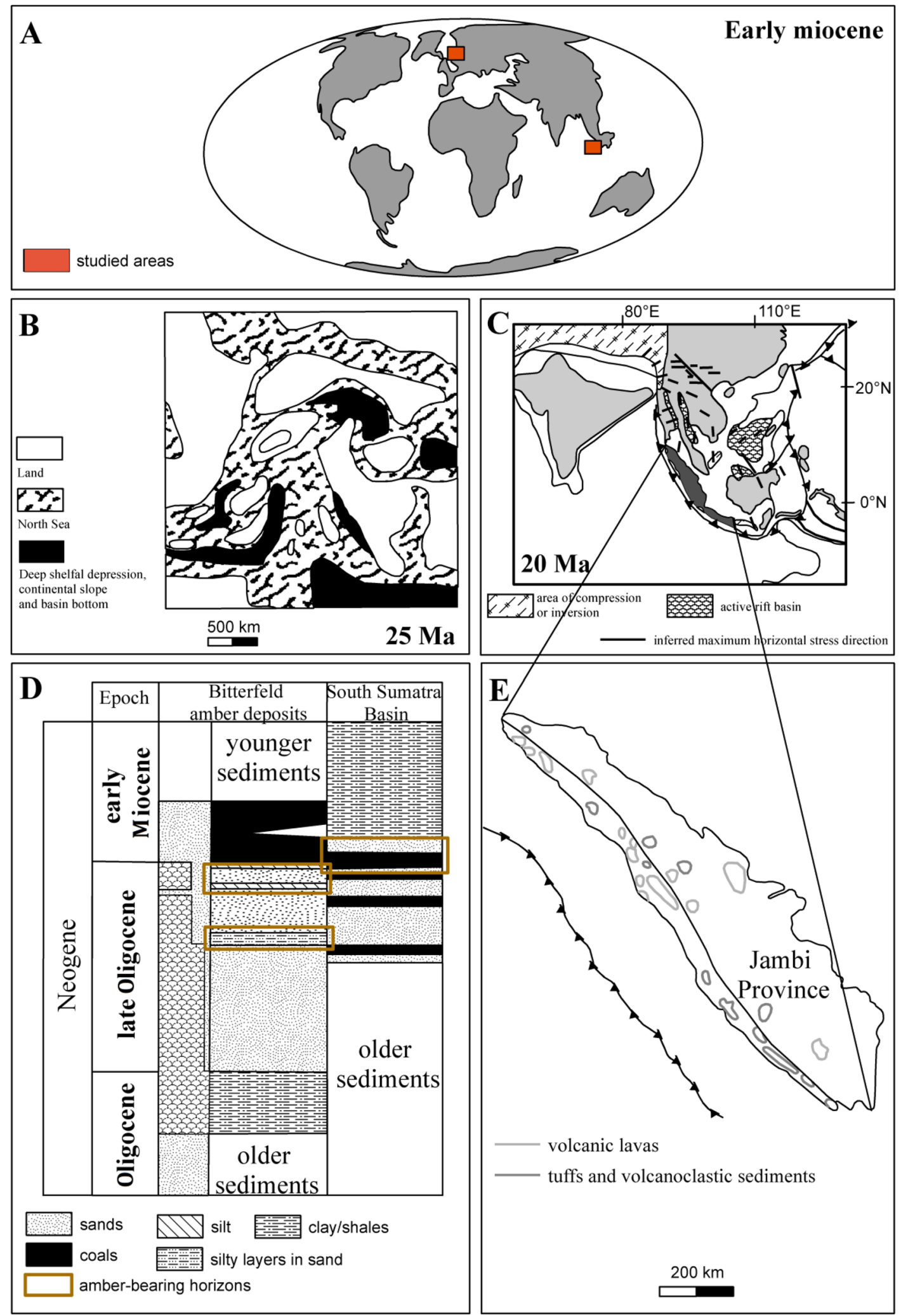

Figure 1. (A) Location of the Sumatra Island and Bitterfeld deposit (Germany) on the world map ${ }^{16}$; (B) The Bitterfeld region in the middle Miocene $(25 \mathrm{Ma})^{40}$; (C) Tectonic map of South Asia including Sumatra Island $(20 \mathrm{Ma})^{16,39}$; (D) The stratigraphy of South Sumatra Basin and Bitterfeld amber deposits ${ }^{16,41,46}$; (E) volcanic units on the map of the Sumatra ${ }^{46}$. 


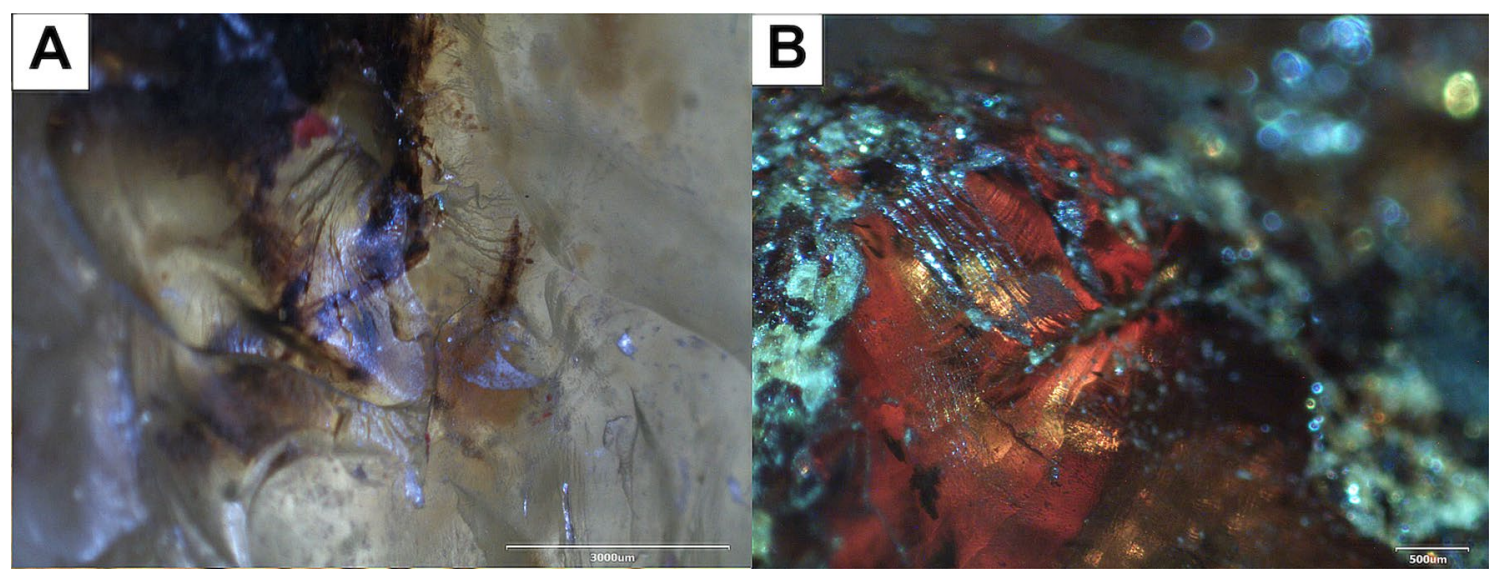

Figure 2. Images from a stereoscopic microscope; (A) numerous, mainly organic (dark) but also mineral and fluid inclusions in Sumatran resin; (B) the heterogeneous structure of Bitterfeld glessite.

\begin{tabular}{|l|l|l|}
\hline Parameter & Fossil resin from Sumatra Island & Glessite from Bitterfeld \\
\hline Arithmetic mean of microhardness Hav $\left(\mathrm{kG} / \mathrm{mm}^{2}\right)$ & 26.30 & 27.44 \\
\hline Range of variability $\left(\mathrm{kG} / \mathrm{mm}^{2}\right)$ & $19.62-33.49$ & $14.12-40.33$ \\
\hline Standard deviation & 3.66 & 7.98 \\
\hline Standard deviation of arithmetic mean & 0.819 & 1.78 \\
\hline Student's t factor & 2.09 & 2.09 \\
\hline Expanded uncertainty & 1.71 & 3.73 \\
\hline Microhardness value $\mathrm{x}\left(\mathrm{kG} / \mathrm{mm}^{2}\right)$ & $26.29 \pm 1.7$ & $27.44 \pm 3.73$ \\
\hline Relative error $\varepsilon \pm(\%)$ & 6.50 & 13.59 \\
\hline
\end{tabular}

Table 1. Microhardness of fossil resins from Sumatra and glessite from Bitterfeld.

upper level of the late Oligocene Cottbus Formation, which consists of sediments of marine, fluvial and limnic origin $^{27,47-50}$. The pieces of the resin are found in clay to sandy layers, associated with coal overgrowth and light dioctahedral mica. The resins-bearing sediments overlay the coal deposits ${ }^{50}$. The presence of marine plankton and glauconite suggests that these sediments were a result of ingress from the basin of north-west Europe ${ }^{29}$. Recently, age of the fossil resins-bearing sediments in Bitterfeld region was assigned to late Oligocene (Chattian; 23.0-28.1 Ma $)^{33,49}$.

The palaeoenvironment of Europe during the Tertiary period was also influenced by warm and humid climate prevailing over the growth of forests, where conifers and other flowering plants, ferns and mosses coexist ${ }^{50}$. Moreover, large areas with the savanna-like character were also present in the environment. Some areas, like swamp forests, were frequently flooded with water. At that time, subtropical vegetation in the area of present Europe was more abundant than in the Sundaland, and had a larger territorial range due to the Eocene climate optimum.

\section{Results and discussion}

The specimens of transparent variety of Sumatran resin, selected for detailed tests, are usually over a dozen $\mathrm{mm}$ in diameter (four samples). Specimens of German resins, glessite (tree samples), were also of similar size. Unlike the German specimens, the Sumatran resins show clear blue fluorescence under Schneider UV light, with $365 \mathrm{~nm}$ wavelength (Fig. 8).

Sumatran samples have distinctive visible characteristics under a stereoscopic microscope. The homogeneity of their yellowish colour was only disturbed by local streaks of congealed resin and low number of very small, organic inclusions, probably remains of wood tissue or bark as well as microspores of oval shapes (Fig. 2A). German resin samples are darker, brown-red and translucent. The number and varieties of inclusions in these resins seems to be greater (Fig. 2B).

The measured microhardness $(\mathrm{H})$ of the Indonesian and German samples differed slightly. The $\mathrm{H}$ values $(n=30)$ varied for four samples of Sumatran resins within a narrow range: the minimum $\mathbf{H}_{\mathrm{vmin}}=19.62$ $(192.41 \mathrm{MPa})$ and the maximum $\mathbf{H}_{\mathrm{vmax}}=33.49(328.42 \mathrm{MPa})$, the average $\left(\mathbf{H}_{\mathrm{va}}\right)$ value is $26.30 \mathrm{kgf} / \mathrm{mm}^{2}$ $(257.91 \mathrm{MPa}) ; \mathbf{S D}=3.66 \mathrm{kgf} / \mathrm{mm}^{2}(35.89 \mathrm{MPa})$. In the case of German specimens (three samples), microhardness values varied more significantly, from 14.12 to $40.33 \mathrm{kgf} / \mathrm{mm}^{2}(138.47-395.50 \mathrm{MPa})$, the average $\left(\mathbf{H}_{\mathrm{va}}\right)$ value was $27.44 \mathrm{~kg} / \mathrm{mm}^{2}(269.09 \mathrm{MPa}) ; \mathrm{SD}=7.98 \mathrm{kgf} / \mathrm{mm}^{2}(78.26 \mathrm{MPa})$. The results are summarized in Table 1 .

The development of spectroscopic methods constituted a breakthrough in the fossil resin studies, and have brought new possibilities in terms of their characterization and identification ${ }^{4}$. The FT-IR studies of Sumatran resins, previously performed by Kosmowska-Ceranowicz and Vávra ${ }^{35}$ and Matuszewska ${ }^{9}$, have shown that their 


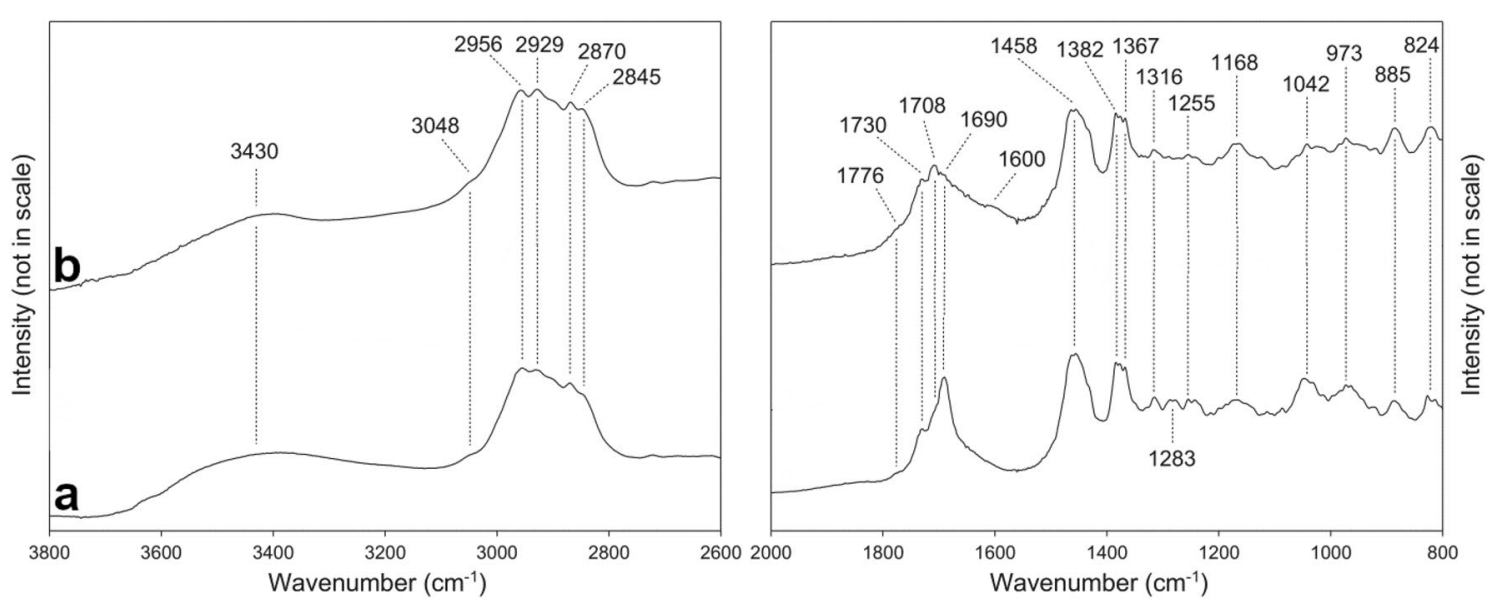

Figure 3. FT-IR spectra of Bitterfeld glessite (a) and Sumatran fossil resin (b).

spectra were very similar to the spectra of glessite from the Bitterfeld deposits. Any observable differences should reflect the transformation processes occurring during their diagenesis as they originate from similar biological angiosperm precursors ${ }^{20,32}$.

The comparative results of our FT-IR studies of Sumatran and German resins (Fig. 3) confirmed those observations, however, some differences in the shape of the spectra in the region closed to $\sim 1700 \mathrm{~cm}^{-1}$ were noticed (so-called fingerprint area). The Bitterfeld glessite (Fig. 3a) has the most symmetric $\mathrm{C}=\mathrm{O}$ vibration band with a maximum of $1690 \mathrm{~cm}^{-1}$, while Sumatran resins show bands at 1776, 1730, 1708 and $1690 \mathrm{~cm}^{-1}$. Peak splitting of $\mathrm{C}=\mathrm{O}$ band was observed on glessite spectra. This suggested that the surrounding environment of the carbonyl group is different in comparison to that of the analysed Sumatran specimens. The characteristic band for glessite occurs at $\sim 1644 \mathrm{~cm}^{-1}$ while in the case of Sumatran resins, it is at a lower wavenumber of $1600 \mathrm{~cm}^{-1}$. The $1644 \mathrm{~cm}^{-1}$ band is characteristic of the exocyclic methylene group (vibration of double bond) while the band at $\sim 1600 \mathrm{~cm}^{-1}$ could be assigned to the ester group ${ }^{4}$. Apart from those differences the spectra of both resin varieties are very similar within the range of $1350-800 \mathrm{~cm}^{-1}$, where additional bands occur, due to vibrations of the C-C and $\mathrm{C}-\mathrm{H}$ bonds. Hence, these results confirmed that the most diagnostic IR bands occur in the $1800-1600 \mathrm{~cm}^{-1}$ region. The presence of the ester group on the Sumatran resins IR spectra suggests that polymerization (polyestrification) processes were involved in fossilization ${ }^{10,16}$. However, in the case of glessite, the resin was likely altered by the oxidation process. These findings could be well correlated with the geological background of studied resins. Glessite deposits were likely formed in a shallow-marine environment in the presence of dissolved oxygen.

Raman spectroscopic method (RS) is becoming widely used for geological purposes. It is sensitive and selective tool for the analysis of the organic materials. Over the last few years RS has also been adopted for studies of fossil resins mostly due to the simplicity of its use and non-destructive character ${ }^{10,15,51}$. Raman Spectroscopy is a method complementary to Infrared Spectroscopy as it enables identification of additional functional groups in IR spectra. Therefore, it is believed that RS could be the basis for further differentiation of fossil resins. Moreover, the shape of the Raman spectra of fossil resins is considered as an indicator of their maturation grade. Comparative Raman spectroscopic studies of differently aged fossil resins performed by Winkler et al. ${ }^{8}$ have shown, that their maturation processes are reflected in RS spectra details; nevertheless, some influences of thermal events during resin fossilization on these spectra shape were also observed. In the studied case, the intention was to identify Raman spectra similarities and/or differences between diversely aged fossil resins in relation to their formation and alteration environments.

Fossil resins from Sumatra Island produce similar Raman spectra to those of the glessite (Fig. 4). The RS spectra of all analysed samples were not obscured by the presence of water and hydroxyl groups and bands from symmetric vibrations $\mathrm{C}-\mathrm{C}$ and $\mathrm{C}=\mathrm{C}$ were also clearly visible. The most intensive and simultaneously most diagnostic bands for the interpretations of maturation processes of fossil resins are $\sim 1640 \mathrm{~cm}^{-1}$ and $\sim 1440 \mathrm{~cm}^{-1}$ bands. The $1640 \mathrm{~cm}^{-1}$ band is related to the stretching vibrations of $\mathrm{C}=\mathrm{CH}_{2}$ (unsaturated hydrocarbons), while the $1440 \mathrm{~cm}^{-1}$ band is usually assigned to the deformation mode of the $\mathrm{CH}_{2}$ group or an asymmetric deformation of $\mathrm{CH}_{3}$ groups with unsaturated $\mathrm{CH}_{2}$ groups ${ }^{8}$. In the studied case, those diagnostic bands are shifted to the higher frequencies of $\sim 1450$ and $\sim 1646 \mathrm{~cm}^{-1}$ (Fig. 4) respectively, but they are clearly distinguishable (the signals are at least three times higher than background). During diagenetic processes, cyclization and compound cross-linking lead to a decrease of double bonds. It may be assumed, that the first stage of diagenetic processes leads to the formation of unsaturated compounds (with one or more double bond) and further cross-linking/ polymerization or cyclization ${ }^{52}$. Therefore, the ratio of intensity of a signal at $1646 \mathrm{~cm}^{-1}$ and $1450 \mathrm{~cm}^{-1}\left(\mathrm{I}^{1646}\right)$ $\mathrm{I}^{1450}$ ) may be interpreted as a degree of fossil resin maturation. In the studied case, the band of $\sim 1450 \mathrm{~cm}^{-1}$ has a greater intensity than $\sim 1646 \mathrm{~cm}^{-1}$ on both spectra. The intensity ratio of $\sim 1646 \mathrm{~cm}^{-1} / 1450 \mathrm{~cm}^{-1}$ is 0.56 for the resin from Sumatra and 0.68 for glessite.

Despite the younger age of Sumatran resins (Miocene), their $\mathrm{I}^{1646} / \mathrm{I}^{1450}$ intensity ratio was lower than that of Bitterfeld glessite, dated to the late Oligocene epoch. This may suggest that Sumatran resins underwent more advanced polymerization processes. However, it is worthwhile to mention that transformation processes are not 


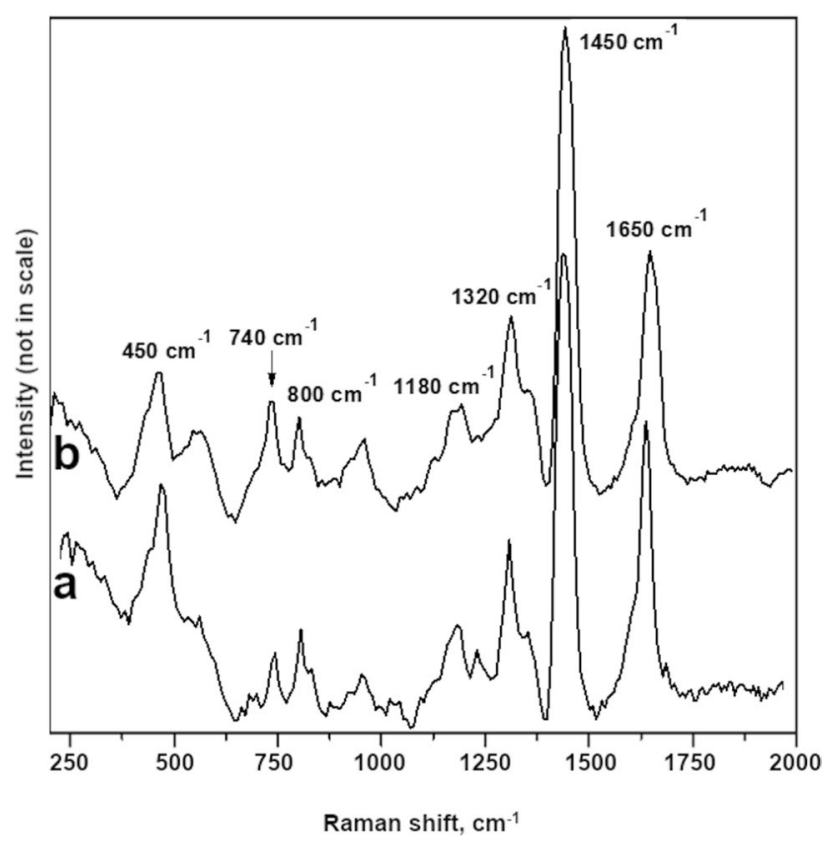

Figure 4. Raman spectra of Bitterfeld glessite (a) and Sumatran fossil resin (b) at a wavelength of $1064 \mathrm{~nm}$.

only caused by age-dependent parameters, such as burial depth and geothermal gradient, but also by certain diastrophic events, i.e. development of magmatic intrusions or volcanic activity. The fossil resins from Sumatra are associated with layers containing tuffs ${ }^{14}$, therefore the volcanically-induced heating could explain why their $\mathrm{I}^{1646} / \mathrm{I}^{1450}$ ratio is lower than previously expected ${ }^{10}$. However, the presence of the opposite process to maturation also cannot be excluded. Oxidation may lead to formation of carbonyl and/or hydroxyl group, which may reverse the cross-linking process. Additionally, some microbiological oxidation of fossil resins in the deposition environment may affect the shape of their Raman spectra. The Sumatran resins are found in a coal layer, thus their depositional environment was rather reducing (dysoxic). In such conditions, processes leading to the formation of unsaturated compounds are prevalent.

Both of the Raman spectra show also relatively many details within the range of 2000 and $200 \mathrm{~cm}^{-1}$ (additional bands at 1320,1180, 800 and $740 \mathrm{~cm}^{-1}$ ). These bands corresponding to the presence of $\mathrm{CH}_{2}$ and $\mathrm{CH}_{3}$ groups in saturated compounds are poorly resolved and visible on spectra. However, in the case of glessite, those bands are more distinguishable (Fig. 4b). It may indicate that Bitterfeld glessite is less matured than Sumatran resin. The presence of the band at $800 \mathrm{~cm}^{-1}$, corresponding to aromatic hydrocarbon deformations ${ }^{53}$, has been previously interpreted as a specific feature of Raman spectra of Indonesian resins ${ }^{10}$. However, this band has also been observed on Raman spectra of Bitterfeld resin. Thus, it could be attributed to the affinity of the resins rather than their diagenesis environment as was previously concluded ${ }^{10}$.

Fluorescence spectroscopy may provide new information on chemical composition of amber. The source of fluorescence is a large number of compounds embedded in fossil resins that are often responsible for their unique appearance ${ }^{54}$. The presence of fluorescent unsaturated and aromatic compounds in fossil resins from different worldwide localities are often reported in literature ${ }^{15,19,32,54-60}$. Fluorescent properties of those compounds are well known and reported in large number of papers ${ }^{61}$. Nevertheless, applicability of this method for study of fossil resin has not been validated in the literature so far ${ }^{4}$. The resin specimens are heterogeneous, anisotropic material, and thus the fluorescence excitation and emission spectra may vary from point to point. Therefore, finding any regularities within fluorescence emission-excitation spectra, and development of fluorescence-based method for identification of fossil resins requires numerous studies on a large number of specimens. In these investigations, fluorescence spectroscopy was used in order to reveal the presence of chemical constituents, which are the most likely responsible for Sumatran resin fluorescence that is observed under UV light, in contrast to non-fluorescing glessite.

Fluorescence spectra of the Sumatran resins (Fig. 5A) resemble the spectra of compounds with four or more aromatic rings ${ }^{62,63}$. Those compounds may form from cyclic terpenes that underwent an aromatization process under temperature and pressure conditions ${ }^{64}$. The presence of such constituents (i.e. perylene) was previously proposed as a source of blue fluorescence in resin observed under UV light ${ }^{54,65}$. However, in a later study, the presence of perylene in blue-fluorescing amber from Far East Russia was not confirmed ${ }^{66}$. Therefore, the interpretation of fluorescence spectra requires further chemical proof.

With regards to glessite, excitation-emission spectrum (Fig. 5B) is different than that of specimen from Sumatra. At the same measurement settings, the fluorescence intensity of glessite is around 20 times lower than that of Sumatran resin. It may be explained by the presence of other non-fluorescent compounds, absorbing the fluorescence light. However, the very strong and sharp emission band at $550 \mathrm{~nm}$ is likely a result of second order diffraction of light at $275 \mathrm{~nm}^{61,67}$. In the case of strongly fluorescing substances, this interference is not observable. 


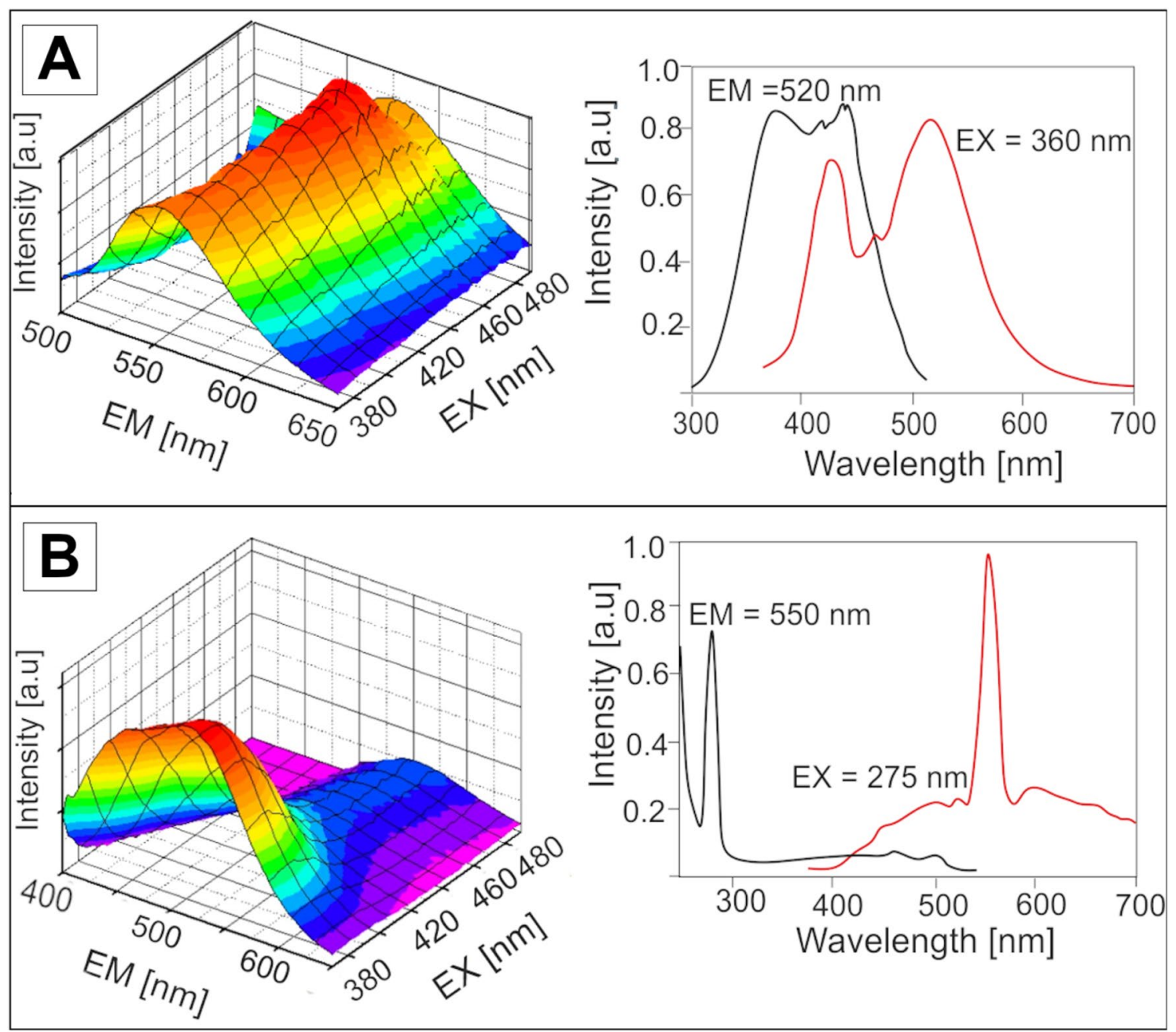

Figure 5. (A) Excitation-emission (EM-EX) spectra of Sumatran resin; (B) excitation-emission (EM-EX) spectra of Bitterfeld glessite.

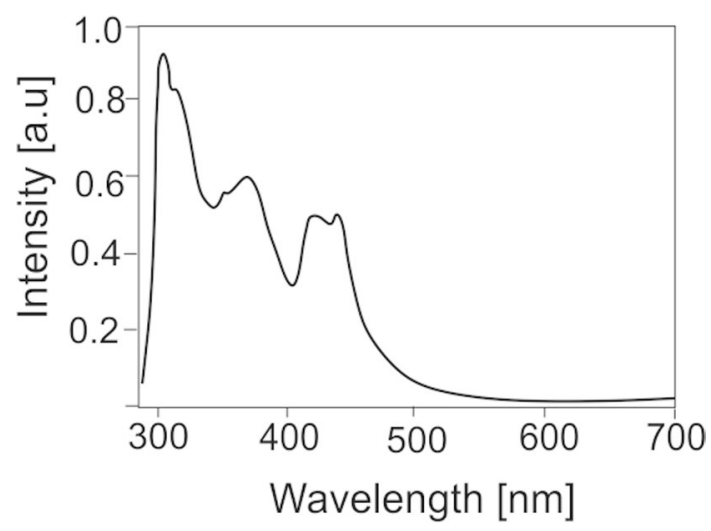

Figure 6. Synchronous fluorescence spectrum of Sumatran resin $\left(\lambda_{\mathrm{em}}=\lambda_{\mathrm{ex}}+18 \mathrm{~nm}\right)$.

Synchronous fluorescence was previously used for identification and determination of polycyclic aromatic carbon in Baltic amber ${ }^{68}$. However, in our study, synchronous fluorescence spectrum $\left(\lambda_{\text {em }}=\lambda_{\text {ex }}+18 \mathrm{~nm}\right)$ was only obtained for Sumatran resin (Fig. 6). The presence of polycyclic aromatic compounds in Sumatran resins is confirmed. Taking together the shape of synchronous fluorescence spectrum and excitation and emission spectrum with the excitation maximum at $360 \mathrm{~nm}$ and the emission maximum at $520 \mathrm{~nm}$, it may be assumed that aromatic compounds with five and more rings were present in chemical structure of Sumatran resin ${ }^{62,69}$. 


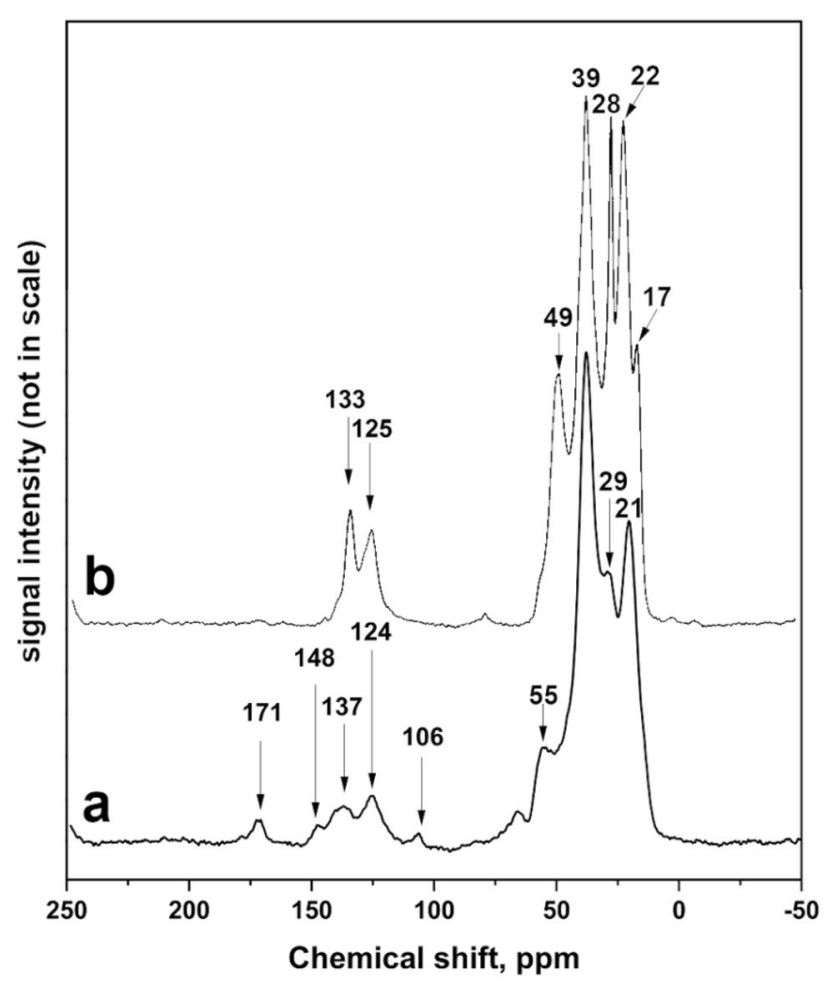

Figure 7. ${ }^{13} \mathrm{C}$ NMR spectra of Bitterfeld glessite (a) and Sumatran fossil resin (b).

It is still unknown whether such compounds are a part of polymeric lattice, or they are merely inclusions. This needs further investigation. The chemical structures of aromatic compounds hold information about sedimentary environment. The compounds may be formed during diagenetic transformation of biological molecules or they may form due to fire or heat effects. Moreover, different aromatic compounds are formed in lacustrine and marine environments. Therefore, the complex excitation-emission spectra needs also further studies by chemometric methods, in order to resolve spectra of fluorescence compounds present in the resin matrices. Fluorescence spectroscopy is a complementary method to infrared and Raman Spectroscopy. Taking together, the results obtained by the use of these methods enable researchers to reveal some information about the chemical structure of the resin without destruction of the specimen.

Recently, application of ${ }^{13} \mathrm{C}$ solid state Nuclear Magnetic Resonance (NMR) spectroscopy in study of fossil resin has been demonstrated to be a powerful method for obtaining botanical and geological information ${ }^{70}$. Examination of the solid-state ${ }^{13} \mathrm{C}$ NMR spectra of fossilized resins (ambers) has generated five groupings of materials based on spectral characteristics related to carbon functionalities ${ }^{70}$. According to this classification, resins from Sumatra and glessite from Bitterfeld belong to the same NMR Group B, the group of resin originating from angiosperms or their precursors (flowering plants) ${ }^{36,71}$. In the spectra of both resins, the most intense resonances were found in the saturated region, $\delta 0-60$ (Fig. 7). These are from saturated carbons typical of terpenoid hydrocarbons ${ }^{70}$. Contrary to Bitterfeld resin, in spectra of Sumatran resin, there were no weaker resonances in the region in which saturated carbon that is substituted with electron-withdrawing groups such as oxygen functionalities $(\delta 60-110)$ resonates. The strong differences were observed in unsaturated region $\delta 100-160$, which contains resonances from carbons of double bonds. Singly substituted alkene carbons $(\mathrm{C}-\mathrm{HC}=\mathrm{CH}-\mathrm{C})$ resonate in the range $\delta 120-145$, unsubstituted alkene carbons $\left(\mathrm{C}=\mathrm{CH}_{2}\right)$ at $\delta$ ca. 110 , and disubstituted alkene carbons $(>\mathrm{C}=\mathrm{C})$ at $\delta \mathrm{ca}$. 150. In spectra of Indonesian resin, narrow and sharp peaks corresponding to resonances at $\delta$ 133 and 125 suggest the presence of aromatic compounds. In the case of Bitterfeld resin, the resonances at both $\delta$ ca. 110 and ca. 150 strongly suggest the presence of an exomethylene or terminal group $\left(>\mathrm{C}=\mathrm{CH}_{2}\right)^{70}$. Peak at $\delta$ ca 170 suggests presence of carboxylic group in structure of German resin. This peak is observed also in spectrum of Baltic amber and corresponds to presence of succinic acid.

Despite the numerous investigations that have been conducted, the chemical composition of various fossil resins needs further elucidations, especially in terms of their diagenetic alterations from plant exudate to their present fossil form. Analytical methods based on mass spectrometry were successfully applied in the fossil resin studies of many authors ${ }^{17,32,56,58,59,72}$. Application of mass spectrometry gives in-depth information about chemical structure of the fossil resins. According to Anderson et al. ${ }^{17}$, the chemical profile of resins compounds can be used for their classification. Additionally, chemical analysis provides information on botanical origin of studied resins and their evolutionary pathways after deposition. The method used commonly for classification and chemical analysis of resins is Py-GC-MS. However, this method is used mainly for analysis of polymerized resin materials ${ }^{17}$. Some resin constituents may not be polymerized; the compounds may be embedded into 


\begin{tabular}{|c|c|c|c|c|c|}
\hline \multicolumn{3}{|l|}{ Fossil resins from Sumatra Island } & \multicolumn{3}{|c|}{ Glessite from Bitterfeld deposits (Yamamoto et al. ${ }^{32}$ ) } \\
\hline Compound & MW & Composition & Compound & MW & Composition \\
\hline \multicolumn{6}{|l|}{ Aromatic hydrocarbons } \\
\hline Toluene & 92 & $\mathrm{C}_{7} \mathrm{H}_{8}$ & \multirow{2}{*}{ 1,4-Dimethyl-1,2,3,4-tetrahydro-naphthalene } & \multirow{2}{*}{160} & \multirow{2}{*}{$\mathrm{C}_{12} \mathrm{H}_{16}$} \\
\hline 1,3-Diethyladamantane & 192 & $\mathrm{C}_{14} \mathrm{H}_{22}$ & & & \\
\hline \multicolumn{6}{|l|}{ Sesquiterpenoids } \\
\hline Cadina-1(10),6,8-triene & 202 & $\mathrm{C}_{15} \mathrm{H}_{22}$ & Cadina-1,6-diene & 204 & $\mathrm{C}_{15} \mathrm{H}_{24}$ \\
\hline Cadina-1,3,5-triene (1-calamenene) & 202 & $\mathrm{C}_{15} \mathrm{H}_{22}$ & Calamenene & 202 & $\mathrm{C}_{15} \mathrm{H}_{22}$ \\
\hline$\beta$-Cadinene & 204 & $\mathrm{C}_{15} \mathrm{H}_{24}$ & Calamene & 202 & $\mathrm{C}_{15} \mathrm{H}_{22}$ \\
\hline a-Muurolene & 204 & $\mathrm{C}_{15} \mathrm{H}_{24}$ & Cadalane & 198 & $\mathrm{C}_{15} \mathrm{H}_{18}$ \\
\hline \multirow[t]{2}{*}{ Aromadendrene } & 204 & $\mathrm{C}_{15} \mathrm{H}_{24}$ & Dihydro-ar-curcumene & 204 & $\mathrm{C}_{15} \mathrm{H}_{24}$ \\
\hline & & & $\beta$-Caryophyllan-2,6-oxide & 222 & $\mathrm{C}_{15} \mathrm{H}_{26} \mathrm{O}$ \\
\hline \multicolumn{6}{|l|}{ Triterpenoids } \\
\hline Betuline & 442 & $\mathrm{C}_{30} \mathrm{H}_{50} \mathrm{O}_{2}$ & 28 -Nor- $\beta$-amyrin isomer & 412 & $\mathrm{C}_{29} \mathrm{H}_{48} \mathrm{O}$ \\
\hline$\alpha$-Amyrin & 426 & $\mathrm{C}_{30} \mathrm{H}_{50} \mathrm{O}$ & 28-Nor- $\alpha$-amyrin isomer & 412 & $\mathrm{C}_{29} \mathrm{H}_{48} \mathrm{O}$ \\
\hline Lupeol & 426 & $\mathrm{C}_{30} \mathrm{H}_{50} \mathrm{O}$ & 28-Nor- $\beta$-amyrone & 410 & $\mathrm{C}_{29} \mathrm{H}_{46} \mathrm{O}$ \\
\hline \multirow[t]{15}{*}{ Urs-12-ene } & 410 & $\mathrm{C}_{30} \mathrm{H}_{50}$ & 28-Nor- $\alpha$-amyrone & 410 & $\mathrm{C}_{29} \mathrm{H}_{46} \mathrm{O}$ \\
\hline & & & 28-Nor- $\beta$-amyrin & 412 & $\mathrm{C}_{29} \mathrm{H}_{48} \mathrm{O}$ \\
\hline & & & $\beta$-Amyrin & 426 & $\mathrm{C}_{30} \mathrm{H}_{50} \mathrm{O}$ \\
\hline & & & 28-Nor- $\alpha$-amyrin & 412 & $\mathrm{C}_{29} \mathrm{H}_{48} \mathrm{O}$ \\
\hline & & & $\alpha$-Amyrin & 426 & $\mathrm{C}_{30} \mathrm{H}_{50} \mathrm{O}$ \\
\hline & & & Allobetul-2-ene & 424 & $\mathrm{C}_{30} \mathrm{H}_{48} \mathrm{O}$ \\
\hline & & & $3 \beta$-Lupeol & 426 & $\mathrm{C}_{30} \mathrm{H}_{50} \mathrm{O}$ \\
\hline & & & Erythrodiol & 442 & $\mathrm{C}_{30} \mathrm{H}_{50} \mathrm{O}_{2}$ \\
\hline & & & Lupeol isomer & 426 & $\mathrm{C}_{30} \mathrm{H}_{50} \mathrm{O}$ \\
\hline & & & Uvaol & 442 & $\mathrm{C}_{30} \mathrm{H}_{50} \mathrm{O}_{2}$ \\
\hline & & & Oleanolic acid & 456 & $\mathrm{C}_{30} \mathrm{H}_{48} \mathrm{O}_{3}$ \\
\hline & & & Ursolic acid & 456 & $\mathrm{C}_{30} \mathrm{H}_{48} \mathrm{O}_{3}$ \\
\hline & & & Oxyallobetulane & 440 & $\mathrm{C}_{30} \mathrm{H}_{48} \mathrm{O}_{2}$ \\
\hline & & & Allobetulin & 442 & $\mathrm{C}_{30} \mathrm{H}_{5} 0 \mathrm{O}_{2}$ \\
\hline & & & Ursa-(1/2/5/6),12-dienolic acid & 452 & $\mathrm{C}_{30} \mathrm{H}_{44} \mathrm{O}_{3}$ \\
\hline
\end{tabular}

Table 2. Summary of chemical analysis of fossil resins from Sumatra Island and glessite from Bitterfeld. $M W$ molecular weight. Bold-biomarkers indicating diagenetic pathways of resins, italics—biomarkers indicating biological origin of resins.

polymer lattice. Therefore, solvent extraction combined with gas chromatography is frequently used for analysis of those compounds ${ }^{32}$.

The chemical composition of both Sumatran and German resin samples contains predominantly sesquiterpenoids and triterpenoids (Table 2). The chemical profile of triterpenoids was similar in resin specimens and consisted of betuline, alfa-amyrin and lupeol (hydroxylupene). The chemical analysis of Sumatran resin confirmed that botanical source was Dipterocarpaceae family of SE-Asian trees ${ }^{20}$. The presence of betuline and luepol is usually considered as characteristic of angiosperms ${ }^{73}$. Both resins contained similar profile of triterpenoids with the oleanane, ursane and lupane structures. This profile indicates botanical source as angiosperm ${ }^{32,74-76}$. The alfa-amyrine, non-altered product of higher plants, and characteristic component of both resins is typical biomarker of an angiosperm plant ${ }^{9,30}$. This component is also believed to originate from Burseraceae-a family of flowering plants found on both areas of present European and Asian continents during the Cenozoic era ${ }^{73}$. The similar botanical affinities of resins may be explained by the fact that during the late Oligocene-Miocene epoch climate was warm and humid contrary to present climates in present areas of Europe and Asia ${ }^{32,77,78}$. Biomarkers, such as aromadendrene-type sesquiterpenoid were only present in solvent extract of Sumatran resin. These components have been previously documented in eucalyptus oils ${ }^{79}$. On the other hand, allobetuline found in the glessite from Bitterfeld indicates birch (Betula) as the possible resin producing tree ${ }^{32}$.

Chemical composition of fossil resins provided also a source of information about their fossilization history. Cadinene-type compounds from sesquiterpenoids group undergo diagenesis to cadalene derivatives ${ }^{80}$. Moreover, sesquiterpenoids have shown the greater susceptibility to diagenetic alteration than pentacyclic triterpenoids ${ }^{81}$. Compounds with a cadinene moiety were found in German and Indonesian resin specimens. In the case of fossil resin from Sumatra Island, the presence of intermediate product of diagenesis-Cadina-1(10),6,8-triene, indicates the relatively advance stage of its maturation ${ }^{80}$. This corroborates the results of Raman Spectroscopy studies. In the Bitterfeld glessite, the presence of cadalane, the final product of diagenetic alteration, suggests more advanced maturation; however, this is not consistent with results of Raman Spectroscopy studies, which indicate less mature resin. This may be explained by the fact that the processes of sesquiterpenoids transformation are 

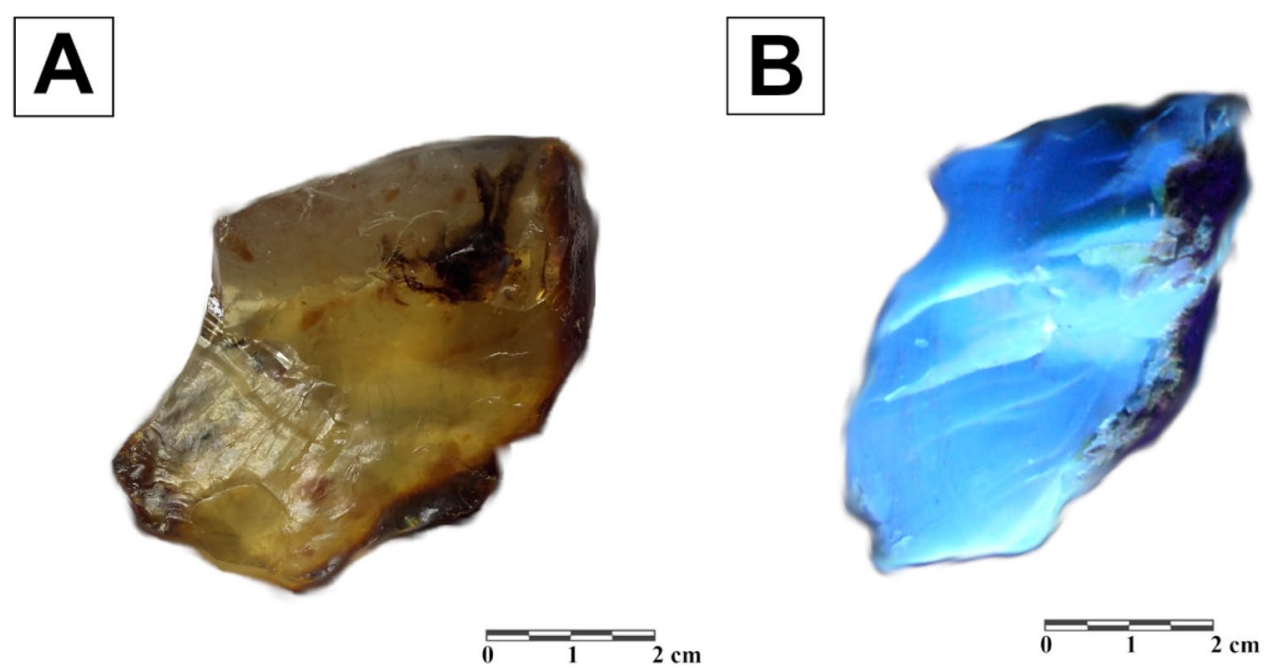

Figure 8. Specimen of Sumatran fossil resin under a white light (A) and UV light-365 nm (B).

affected by the inorganic environment ${ }^{80}$. The glessite occurs in glauconite-rich layers; therefore, the deposition environment is chemically diversified, in some cases, rich in iron. The presence of iron may affect the diagenetic transformations of sesquiterpenoids biomarkers ${ }^{80}$.

In applied analytical conditions, aromatic compounds were not found in Sumatran resin. Source of toluene in resin is likely contamination after excavation and transportation to the laboratory. To explain the presence of polyaromatic compounds in the investigated resin samples, product of diagenesis of amyrin, botulin and lupeol, cannot be excluded ${ }^{64}$.

In conclusion, the fossil resins of a similar botanical origin but a different preservational history were investigated. Both resins from Sumatra Island (Jambi Province, Sarolangun mine) and Germany (Saxony-Anhalt, Bitterfeld deposits) originate from exudates of trees belonging to angiosperms species. However, they were formed in various palaeoenvironmental conditions and deposited in different sedimentological systems, thus they were subjected to different alteration processes from the time of their formation to the present form. Factors which differentiate between these palaeogeographical and geological environments are: solar light, redox conditions, and thermal maturation of resin-bearing sediments (not strictly related to their age). In general, fossil resins from Sumatra Island and Germany were formed under similar palaeogeographical conditions (similar biocenosis of amber-bearing forests, warm and humid climate), but the latitude of their occurrence differed, which corresponds to the various solar light intensity. Therefore, this may influence the resins' chemical signature at the time of their formation. Additionally, in the case of Sumatran resins, dysoxic conditions and volcanic activity likely occurred during their burial. Subsequently, the resins were subjected to various diagenetic alterations when further differentiation was possible due to the different sedimentological and diagenetic systems. Having the knowledge about transformation pathways of organic compounds from burial to present time, one can determine original chemical content of plant exudate. The chemical content is further used in chemotaxonomy of plant species.

In this study, the results obtained with the set of analytical methods confirmed that Sumatran fossil resins show significant similarity to the glessite from Bitterfeld. Both resins have similar spectroscopic characteristics, as IR and RS spectra recorded for them are nearly identical. The most important feature, which differentiates resins, is chemical composition, especially the presence of some components responsible for producing their fluorescence spectra (aromatic hydrocarbons). Hence, Gas Chromatography-Mass Spectrometry and Fluorescence Spectroscopy were the most sensitive tools to identify any variations of chemistry between Sumatran and German resins. Nuclear Magnetic Resonance spectroscopy permits additional differentiation of resins, which allows to track changes in spectra according to resin maturity and diagenetic history.

The degree of compound aromatization may be used for assessment of the resin maturation. This can be easily indicated by Fluorescence Spectroscopy, without destruction of the resins. The results of ${ }^{13} \mathrm{C}$ NMR study indicated the presence of carboxylic acids, oxidation products of terpenoids, in Bitterfeld resins. The mechanism of carboxylic acid formation in fossil resin is still disputable.

\section{Material and methods}

Material. For this study, the samples of resins from Sumatra (Fig. 8) were provided by Dr. Robert Girulski (University of Wroclaw, Poland). The specimens of transparent resin with light yellow colouration (I type described by Naglik et al. ${ }^{16}$ ), are considered as the less altered, and were taken for further analytical tests. Glessite samples from Bitterfeld (Fig. 9) came from Prof. Günter Krumbiegel's collection housed in Halle (Germany) and were provided by his son, Dr. Anselm Krumbiegel.

Stereoscopic microscope. Internal structures of resins and inclusions occurring in them were observed with the Motic SNZ-168 stereoscopic microscope, coupled with a Lusis digital camera (Model CMOS HC- 


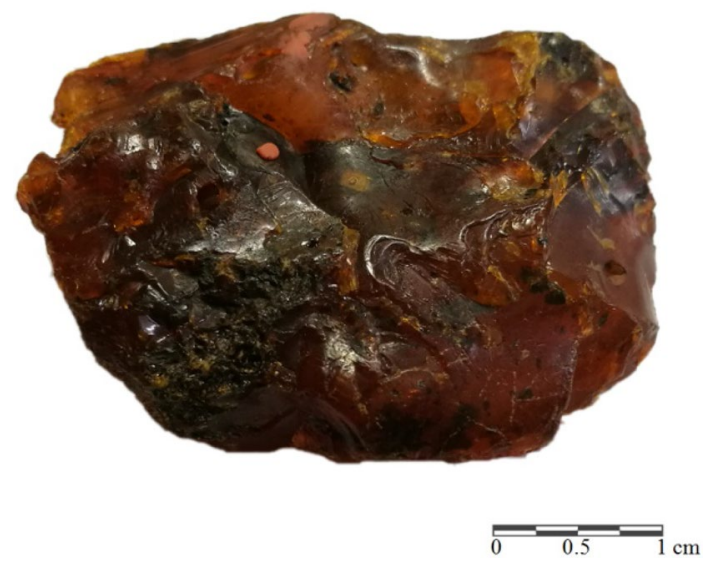

Figure 9. A Bitterfeld glessite sample.

30MU) and Huwitz Panasis software for macrophoto documentation. The research was performed in a laboratory of the Faculty of Geology, Geophysics and Environmental Protection of AGH UST, Kraków, Poland.

Microhardness testing. Determinations of microhardness parameters were performed using a Russian made tester PMT-3 in the Gemological Laboratory of the Faculty of Geology, Geophysics and Environmental Protection of AGH UST, Kraków, Poland. The testing procedure was performed according to the Vickers method as described elsewhere ${ }^{7}$. It involves pressing a quadrangular diamond pyramid with an dihedral angle equal to $136^{\circ}$ on the flat surface of the tested material. The tests were performed on the smooth surfaces of each of the four samples of resins from Sumatra and three samples of glessite, and the measurements were repeated 30 times. Subsequently, the results obtained were statistically processed.

Fourier Transform Infrared Spectroscopy (FT-IR). IR spectra of analytical resin samples were collected in a laboratory the Faculty of Geology, Geophysics and Environmental Protection of AGH UST, Kraków, Poland, using a Nicolet 6700 spectrometer (Thermo Scientific, USA) with 64 scans at $4 \mathrm{~cm}^{-1}$ resolution in the $4000-400 \mathrm{~cm}^{-1}$ mid-region. A mixture of $3 \mathrm{wt} \%$ sample/KBr was analysed by diffuse reflectance infrared Fourier transform spectroscopy (DRIFT) using a Praying Mantis Diffuse Reflection Accessory (Harrick). The DRIFT technique applied to the samples gave a higher signal to noise ratio compared with methods based on preparation of $\mathrm{KBr}$ pellet.

Raman Spectroscopy. The Raman spectra of resins were recorded using the handheld Near-Infrared Raman spectrometer Progeny ResQ (Rigaku, Japan), equipped in spectrometer with InGaAs detector was loan from Tusnovics Instruments Ltd., Kraków (Poland). The spectrometer equipped with $1064 \mathrm{~nm} \mathrm{Nd:YAG} \mathrm{laser}$ line excitation, with a maximum power value of $490 \mathrm{~mW}$. The laser line at $1064 \mathrm{~nm}$ was chosen in order to avoid strong fluorescence background ${ }^{10}$. The spectra were recorded in the range from 2000 to $200 \mathrm{~cm}^{-1}$ with $8 \mathrm{~cm}^{-1}$ resolution.

Fluorescence Spectroscopy (FS). Fluorescence emission and excitation spectra were measured with an LS900 spectrofluorometer from Edinburgh Instr. in the Institute of Optoelectronic in the Military University of Technology, Warsaw, Poland. The source of the excitation was a $450 \mathrm{~W}$ xenon lamp. The spectra were recorded at a resolution of $2 \mathrm{~nm}$. Flat polished plates were cut from the specimens and ground. Fluorescence spectra were measured from the surface of the samples to avoid the internal filter effects. Emission-excitation spectra (EXEM) were obtained with $5 \mathrm{~nm}$ resolution. Synchronous fluorescence spectra was obtained through the simultaneous scanning of the excitation and the emission with a fixed $18 \mathrm{~nm}$ wavelength difference between them.

Nuclear Magnetic Resonance $\left({ }^{13}\right.$ C CP-MAS NMR). $\quad$ NMR analyses were made in the Nuclear Magnetic Resonance Laboratory at Łukasiewicz Research Network-PORT Polish Center for Technology Development, Wrocław (Poland). The measurements were carried out on a 14.1T Bruker III Advanced HD spectrometer operating at the ${ }^{13} \mathrm{C}$ frequency of $150.13 \mathrm{MHz}$, equipped with a broadband $3.2 \mathrm{~mm}$ Cross Polarization Magic Angle Spinning (CP MAS) probe. Powder samples of 100-200 mg were packed into a $3.2 \mathrm{~mm}$ zirconia rotor. The spin rate was $20 \mathrm{kHz}$. Pulse power was $83 \mathrm{~W}$ and pulse width was $4 \mu \mathrm{s}$. The optimized contact time for cross-polarization was 2 ms. 4096 points were collected for one scan. The sample measurement was the sum of 8500 scans. Glycine was applied as a reference for the chemical shift (176.0 ppm).

Gas Chromatography-Mass Spectrometry (GC-MS). GC-MS analyses were made in a laboratory of the Earth Science Institute, the Slovak Academy of Sciences in Banská Bystrica (Slovakia). Small amount of Sumatran resin (20-50 mg) was pulverized in an agate mortar and transported into $2 \mathrm{ml}$ vials. Then, a mixture 
of the organic solvents dichloromethane and methanol (9:1) was added to the vial and left for three days at $50{ }^{\circ} \mathrm{C}$. Thereafter, samples were sonicated and filtered on Pasteur pipets filled with silica wool and connected to a glass manifold with a vacuum. Extracts were analysed by GC-MS (TraceGC Ultra-ITQ900, Thermo Fisher Scientific), on $60 \mathrm{~m}$ nonpolar capillary column Zebron ZB5, connected to an ion-trap quadrupole with an electronimpact ionization for collection of mass spectra. Helium was used as a carrier gas. The temperature program was the following: $60 \mathrm{~min}$ at initial temperature of $70^{\circ} \mathrm{C}$, with one minute holding, than ramped to $1800^{\circ} \mathrm{C}$ at $30{ }^{\circ} \mathrm{C} \mathrm{min}{ }^{-1}$ rate, and after that, ramped to $330^{\circ} \mathrm{C}$ at $4{ }^{\circ} \mathrm{C} \mathrm{min}{ }^{-1}$ rate. Finally, temperature was kept at $330{ }^{\circ} \mathrm{C}$ for $16 \mathrm{~min}$. Analysed data were processed with the Xcalibur software with mass spectra library (NIST library), obtained mass spectra were additionally analysed by comparison to mass spectra reported in literature. The GC-MS results obtained for resin from Sumatra were discussed alongside GC-MS glessite data published by Yamamoto et al. ${ }^{32}$.

Received: 1 July 2020; Accepted: 6 October 2020

Published online: 26 October 2020

\section{References}

1. Seyfullah, L. J. et al. Production and preservation of resins-Past and present. Biol. Rev. 93, 1684-1714 (2018).

2. Ragazzi, E. \& Alexander, R. S. Amber. In Encyclopedia of Geobiology (eds Reitner, J. \& Thiel, V.) 24-36 (Springer, New York, 2011).

3. Truiča, G. I. et al. A multi-analytical approach to amber characterization. Chem. Papers. 68, 15-21 (2014).

4. Drzewicz, P., Natkaniec-Nowak, L. \& Czapla, D. Analytical approaches for studies of fossil resins. TrAC Trend. Anal. Chem. 85, 75-84 (2016).

5. Matuszewska, A., Gołąb, A. \& Salomon, A. Mikrotwardość bursztynu i jego imitacji. Polski Jubiler. 1(19), 26-29 (2002) (in Polish).

6. Czapla, D., Natkaniec-Nowak, L. \& Drzewicz, P. Microhardness as a method for investigation of fossil resins. Geol. Geophys. Environ. 42(1), 63-64 (2016).

7. Stach, P. et al. An attempt to correlate the physical properties of fossil and subfossil resins with their age and geographic location. J. Polym. Eng. 39(8), 716-728 (2019).

8. Winkler, W., Kirchner, ECh., Asenbaum, A. \& Musso, M. A Raman spectroscopic approach to the maturation process of fossil resins. J. Raman Spectrosc. 32(1), 59-63 (2001).

9. Matuszewska, A. The comparison of structure and properties of fossil resins of the glessite type (from Germany, Europe) and of the dammar type (from Malaysia, Southeast Asia). Mauritiana (Altenburg) 37, 42-57 (2019).

10. Naglik, B. et al. Fossil resins-constraints from portable and laboratory near-infrared raman spectrometers. Minerals 10, 104-120 (2020).

11. Zhao, J., Ragazzi, E. \& McKenna, G. B. Something about amber: Fictive temperature and glass transition temperature of extremely old glasses from copal to Triassic amber. Polymer 54(26), 7041-7047 (2013).

12. Pagacz, J., Stach, P., Natkaniec-Nowak, L., Naglik, B. \& Drzewicz, D. Preliminary thermal characterization of fossil resins from different botanical sources and geological environments. J. Therm. Anal. Calorim. 138(6), 4279-4288 (2019).

13. Pagacz, J., Naglik, B., Stach, P., Drzewicz, P. \& Natkaniec-Nowak, L. Maturation processes of natural resins recorded in their thermal properties. J. Mater. Sci. 55(10), 4504-4523 (2020).

14. Kosmowska-Ceranowicz, B., Sachanbiński, M. \& Łydżba-Kopczyńska, B. Analytical characterization of "Indonesian amber" deposits: Evidence of formation from volcanic activity. Baltica 30(1), 55-60 (2017).

15. Jehlička, J., Jorge Villar, S. E. \& Edwards, H. G. M. Fourier transform Raman spectra of Czech and Moravian fossil resins from freshwater sediments. J. Raman Spectrosc. 35(8-9), 761-767 (2004).

16. Naglik, B. et al. Evolutionary history of fossil resin from Jambi Province (Sumatra, Indonesia) based on physico-chemical studies. Minerals 8, 95-107 (2018).

17. Anderson, K. B. \& Winans, R. E. Nature and fate of natural resins in the geosphere. Evaluation of pyrolysis-gas chromatography/ mass spectrometry for the analysis of natural resins and resinites. Anal. Chem. 63, 2901-2908 (1991).

18. Anderson, K. B., Winans, R. \& Botto, R. The nature and fate of natural resins in the geosphere-II. Identification, classification and nomenclature of resinites. Org. Geochem. 18, 829-841 (1992).

19. Anderson, K. B. \& Botto, R. E. The nature and fate of natural resins in the geosphere-III. Re-evaluation of the structure and composition of Highgate Copalite and Glessite. Org. Geochem. 20, 1027-1038 (1993).

20. Brackman, W., Spaargaren, K., Van Dongen, J. P. C. M., Couperus, P. A. \& Bakker, F. Origin and structure of the fossil resin from an Indonesian Miocene coal. Geochim. Cosmochim. Acta. 48(12), 2483-2487 (1984).

21. Langenheim, J. H. Higher plant terpenoids: A phytocentric overview of their ecological roles. J. Chem. Ecol. 20, 1223-1280 (1994).

22. Lambert, J. B., Johnson, S. C., Shawl, C. E. \& Poinar, G. O. Fossil resin from Asia. Anc. Biomol. 3, 29-35 (1999).

23. Bąk, M., Natkaniec-Nowak, L.,Drzewicz, P., Czapla, D. \& Bogdasarov, M. Ambrosia-like fungi in fossil resin from Jambi Province in Sumatra Island-Possible phoretic organisms interacted with invaded insects. in Mat. 17th Czech-Slovak-Polish Palaeontological Conference, Krakow, 20-21 October 2016.

24. Natkaniec-Nowak, L., et al. Fossil resins from Jambi province (Sumatra, Indonesia)-Proxy indicators of palaeonvironment and palaeoclimate of Sundaland. in ESASGD 2016: International conferences on Earth Sciences and Sustainable Geo-resources Development: Hanoi, November 12-15, 2016: program book.

25. Leelawatanasuk, Th. et al. The characteristic of amber from Indonesia. Aust. Gemmol. 25(4), 142-145 (2013).

26. Krumbiegel, G. \& Kosmowska-Ceranowicz, B. Vorkommen von Glessit, Siegburgit (?) und Krantzit im Tertiär Mitteldeutschlands (Bitterfeld, Niederlausitz). Fundgrube. 26, 78-81 (1990) (in German).

27. Krumbiegel, G. \& Kosmowska-Ceranowicz, B. Fossile Harze der Umgebung von Halle (Saale) in der Sammlung des Geiseltalmuseums der Martin-Luther-Universität Halle-Wittenberg. Wiss. Z. Univ. Halle. XXXXI. M 6, 5-35 (1992) (in German).

28. Krumbiegel, G. Glessit, ein tertiäres Harz von Bedecktsamern. Fossilien 10, 83-90 (1993) (in German).

29. Kosmowska-Ceranowicz, B. \& Krumbiegel, G. Bursztyn bitterfeldzki-saxonski i inne żywice kopalne z okolic Halle/NRD. Prz. Geol. 38, 394-400 (1990) (in Polish).

30. Kosmowska-Ceranowicz, B., Krumbiegel, G. \& Vávra, N. Glessit, ein tertiäres Harz von Angiospermen der Familie Burseraceae. Neues Jb. Geol. Paläont. Abh. 187, 299-324 (1993) (in German).

31. Kosmowska-Ceranowicz, B. Bursztyn i inne żywice kopalne świata. Glessyt. Pol. Jubiler 1, 31-33 (1999) (in Polish).

32. Yamamoto, S., Otto, A., Krumbiegel, G. \& Simoneit, B. R. T. The natural product biomarkers in succinite, glessite and stantienite ambers from Bitterfeld, Germany. Rev. Palaeobot. Palyno. 140(1-2), 27-49 (2006).

33. Wolfe, A. P., McKellar, R. C., Tappert, R., Sodhi, R. N. \& Muehlenbachs, K. Bitterfeld amber is not Baltic amber: Three geochemical tests and further constraints on the botanical affinities of succinite. Rev. Palaeobot. Palyno. 225, 21-32 (2016).

34. Colchester, D. M., Webb, G. \& Emseis, P. Amber-like fossil resin from north Queensland, Australia. Gemmologist 22, 378-834 (2006). 
35. Kosmowska-Ceranowicz, B. \& Vávra, N. Infrared Spectra of Fossil Resins, Subfossil Resins and Selected Imitation of Amber (Polish Academy of Science Museum of Earth, Warsaw, 2015).

36. Lambert, J. B., Levy, A. J., Santiago-Blay, J. A. \& Wu, Y. Nuclear magnetic resonance characterization of Indonesian Amber. Life Excitement Biol. 1, 136-155 (2013).

37. Adiwidjaja, P. \& Decoster, G. L. Pre-Tertiary paleotopography and related sedimentation in South Sumatra. in 2nd Annual Convention Proceedings. 4-5 (1973).

38. Young, R. \& Atkinson, C. D. A review of Talang Akar Formation (Oligo-Miocene) reservoirs in the offshore areas of Southeast Sumatra and Northwest Java. In Proceedings of the Clastic Rocks and Reservoirs of Indonesia: A Core Workshop 177-210 (Indonesian Petroleum Association, Jakarta, 1993).

39. Friederich, M. C., Moore, T. A. \& Flores, R. M. A regional review and new insights into SE Asian Cenozoic coal-bearing sediments: Why does Indonesia have such extensive coal deposits? Int. J. Coal Geol. 166, 2-35 (2016).

40. Rasser, M. W. et al. Palaeogene and Neogene. In The Geology of Central Europe: Mesozoic and Cenozoic Vol. 2 (ed. McCann, T.) 1031-1139 (Geol. Soc. London, London, 2009).

41. Eissmann, L. Tertiary geology of the Saale-Elbe region. Quat. Sci. Rev. 21(11), 1245-1274 (2002).

42. Barthel, W. \& Hetzer, H. Bernstein-Inklusen aus dem Miozän des Bitterfelder Raumes. Zeitschr. Angew. Geol. 28(7), 314-336 (1982) (in German).

43. Fuhrmann, R. \& Borsdorf, R. Die Bernsteinarten des Untermizoäns von Bitterfeld. Zeitschr. Angew. Geol. 32(1), 309-316 (1986) (in German).

44. Krumbiegel, G. Der Bitterfelder Bernstein (Succinit). In Klassische Fundstellen der Paläontologie Vol. III (ed. Weidert, W. K.) 11-12 (Goldschneck Verlag, Weinstadt, 1995) (191-204, 268-269 [in German]).

45. Krumbiegel, G. Bernstein (Succinit)-Die Bitterfelder Lagerstätte. In Bernstein, Tränen der Götter Vol. 64 (eds Ganzelewski, M. \& Slotta, R.) 89-100 (Veröffentlichungen des Deutschen Bergbau-Museums, Verlag Glückauf, Essen, 1996) (in German).

46. Barber, A. J., Crow, M. J. \& Milsom, J. Sumatra: geology, resources and tectonic evolution. Geological Society Memoirs Vol. 31 (The Geological Society, London, 2005).

47. Kosmowska-Ceranowicz, B. \& Krumbiegel, G. Geologie und Geschichte des Bitterfelder Bernsteins und anderer fossiler Harze. Hallesches Jahrb. Geowiss. 14, 1-25 (1989) (in German).

48. Krumbiegel, G. Beckerit aus dem Tagebau Goitsche bei Bitterfeld Sachsen-Anhalt, Deutschland. In Investigations into Amber, Proceedings of the International Interdisciplinary Symposium: Baltic Amber and other Fossil Resins, 2-6 September 1997, Gdansk (eds Kosmowska-Ceranowicz, B. \& Paner, H.) 231-239 (The Archaeological Museum in Gdansk, Gdansk, 1999).

49. Knuth, G., Koch, T., Rappsilber, I. \& Volland, L. Zum Bernstein im Bitterfelder Raum-Geologie und genetische Aspekte. Hallesches Jahrb. Geowiss. 24, 35-46 (2002).

50. Rappsilber, I., Krumbiegel, G. \& Wimmer, R. Overview of Bitterfeld amber. in The International Amber Researcher Symposium (Gdańsk, 22-23 March 2013).

51. Brody, R. H., Edwards, H. G. M. \& Pollard, A. M. A study of amber and copal samples using FT-Raman spectroscopy. Spectrochim. Acta Part A Mol. Biomol. Spectrosc. 57, 1325-1338 (2001).

52. Kimura, H. et al. A spectroscopic index for estimating the age of amber. Bull. Chem. Soc. Jpn. 79(3), 451-453 (2006).

53. Vandenabeele, P., Grimaldi, D. M., Edwards, H. G. M. \& Moens, L. Raman spectroscopy of different types of Mexican copal resins. Spectrochim. Acta Part A Mol. Biomol. Spectrosc. 59, 2221-2229 (2003).

54. Bellani, V., Giulotto, E., Linati, L. \& Sacchi, D. Origin of the blue fluorescence in Dominican amber. J. Appl. Phys. 97, 016101 (2005).

55. Simoneit, B. R. et al. Cyclic terpenoids of contemporary resinous plant detritus and of fossil woods, ambers and coals. Org. Geochem. 10(4-6), 877-889 (1986).

56. Matuszewska, A. \& Karwowski, Ł. Thin-Layer Chromatography in investigation of the chemical structure of amber. J. Planar Chromatogr. Modern TLC. 13, 140-145 (2000).

57. Otto, A., Simoneit, B. R. \& Rember, W. C. Resin compounds from the seed cones of three fossil conifer species from the Miocene Clarkia flora, Emerald Creek, Idaho, USA, and from related extant species. Rev. Palaeobot. Palyno. 126(3), 225-241 (2003).

58. Chaler, R. \& Grimalt, J. O. Fingerprinting of cretaceous higher plant resins by infrared spectroscopy and gas chromatography coupled to mass spectrometry. Phytochem. Anal. 16, 446-450 (2005).

59. Sonibare, O. O., Hoffmann, T. \& Foley, S. F. Molecular composition and chemotaxonomic aspects of Eocene amber from the Ameki Formation, Nigeria. Org. Geochem. 51, 55-62 (2012).

60. Havelcová, M., Sýkorová, I., Mach, K. \& Dvorák, Z. Organic geochemistry of fossil resins from the Czech Republic. Procedia Earth Planet. 10, 303-312 (2014).

61. Guilbault, G. G. (ed.) Practical Fluorescence (CRC Press, Boca Raton, 1990).

62. Kumke, M. U., Löhmannsröben, H. G. \& Roch, T. Fluorescence spectroscopy of polynuclear aromatic compounds in environmental monitoring. J. Fluoresc. 5, 139-152 (1995).

63. Berlman, I. B. Handbook of Fluorescence Spectra of Aromatic Molecules (Academic Press, New York, 1971).

64. Peters, K., Walters, C. C. \& Moldowan, M. J. The Biomarker Guide (Cambridge Press, Cambridge, 2005).

65. Chekryzhov, I. Y., Nechaev, V. P. \& Kononov, V. V. Blue-fluorescing amber from Cenozoic lignite, eastern Sikhote-Alin, Far East Russia: Preliminary results. Int. J. Coal Geol. 132, 6-12 (2014).

66. Bechtel, A., Chekryzhov, I. Y., Nechaev, V. P. \& Kononov, V. V. Hydrocarbon composition of Russian amber from the Voznovo lignite deposit and Sakhalin Island. Int. J. Coal Geol. 167, 176-183 (2016).

67. Lakowicz, J. R. Principles of Fluorescence Spectroscopy 3rd edn. (Springer, New York, 2006).

68. Matuszewska, A. \& Czaja, M. Aromatic compounds in molecular phase of Baltic amber-synchronous luminescence analysis. Talanta 56(6), 1049-1059 (2002).

69. Kavanagh, R. J., Burnison, B. K., Frank, R. A., Solomon, K. R. \& Van Der Kraak, G. Detecting oil sands process-affected waters in the Alberta oil sands region using synchronous fluorescence spectroscopy. Chemosphere 76(1), 120-126 (2009).

70. Lambert, J. B., Santiago-Blay, J. A., Wu, Y. \& Levy, A. J. Examination of amber and related materials by NMR spectroscopy. Magn. Reson. Chem. 53, 2-8 (2015).

71. Lambert, J. B., Santiago-Blay, J. A. \& Anderson, K. B. Chemical signatures of fossilized resins and recent plant exudates. Angew. Chem. Int. Ed. 47, 9608-9616 (2008).

72. Poinar, G. O. Jr. \& Haverkamp, J. Use of pyrolysis mass spectrometry in the identification of amber samples. J. Balt Stud. 16(3), 210-221 (1985).

73. Modugno, F. \& Ribechini, E. GC/MS in the characterisation of resinous material. In Organic Mass Spectrometry in Art and Archaeology (eds Colombini, M. P. \& Modugno, F.) 215-237 (Wiley, New York, 2009).

74. Kulshreshtha, M. J., Kulshreshtha, D. K. \& Rastogi, R. P. The triterpenoids. Phytochem. 11, 2369-2381 (1972).

75. Pant, P. \& Rastogi, R. P. The triterpenoids. Phytochem. 18, 1095-1108 (1979).

76. Dev, S. Terpenoids. In Natural Products of Woody Plants Vol. 2 (ed. Rowe, J. W.) 691-807 (Springer, New York, 1989).

77. Roth-Nebelsick, A., Utescher, T., Mosbrugger, V., Diester-Haass, L. \& Walther, H. Changes in atmospheric $\mathrm{CO}_{2}$ concentrations and climate from the late Eocene to early Miocene: Palaeobotanical reconstruction based on fossil floras from Saxony, Germany. Palaeogeogr. Palaeoclimatol. Palaeoecol. 205(1), 43-67 (2004).

78. Mach, K. et al. An evaluation of palaeogeography and palaeoecology in the Most Basin (Czech Republic) and Saxony (Germany) from the late Oligocene to the early Miocene. Neues Jahrb. Geol. Palaontol. Abh. 272(1), 13-45 (2014). 
79. Fadel, H., Marx, F., El-Sawy, A. \& El-Ghorab, A. Effect of extraction techniques on the chemical composition and antioxidant activity of Eucalyptus camaldulensis var. brevirostris leaf oils. Z. Lebensm. Unters. Forsch. 208(3), 212-216 (1999).

80. Qin, S., Sun, Y. \& Tang, Y. Long-term, low temperature simulation of early diagenetic alterations of organic matter from conifers: Aliphatic hydrocarbons. Geochem. J. 44(4), 247-259 (2010).

81. Mallick, M., Dutta, S. \& Greenwood, P. F. Molecular characterization of fossil and extant dammar resin extracts: Insights into diagenetic fate of sesqui- and triterpenoids. Int. J. Coal Geol. 121, 129-136 (2014).

\section{Acknowledgements}

The authors thank Dr. Robert Girulski and Dr. Anselm Krumbiegel for providing the resin samples for research. The investigations were financially supported by Polish Geological Institute-National Research Institute, Grant no. 62.9012.2002.00.0 and AGH University of Science and Technology: Grant no. 16.16.140.315. The authors thank Tusnovics Instruments Ltd., Kraków (Poland) for lending the equipment for this study.

\section{Author contributions}

P.D., B.N., M.D.-S., L.N.-N. and P.S. designed the experiments, interpreted the data, wrote the manuscript, and prepared figures and photographs. M.K., J.M., R.M., J.S. and D.K.-B. performed the experiments and interpreted the data.

\section{Competing interests}

The authors declare no competing interests.

\section{Additional information}

Correspondence and requests for materials should be addressed to P.D.

Reprints and permissions information is available at www.nature.com/reprints.

Publisher's note Springer Nature remains neutral with regard to jurisdictional claims in published maps and institutional affiliations.

(c) (i) Open Access This article is licensed under a Creative Commons Attribution 4.0 International License, which permits use, sharing, adaptation, distribution and reproduction in any medium or format, as long as you give appropriate credit to the original author(s) and the source, provide a link to the Creative Commons licence, and indicate if changes were made. The images or other third party material in this article are included in the article's Creative Commons licence, unless indicated otherwise in a credit line to the material. If material is not included in the article's Creative Commons licence and your intended use is not permitted by statutory regulation or exceeds the permitted use, you will need to obtain permission directly from the copyright holder. To view a copy of this licence, visit http://creativecommons.org/licenses/by/4.0/.

(C) The Author(s) 2020 